\title{
Antioxidant activity and fermentative metabolism in the plant Erythrina crista-galli L. under flood conditions
}

\section{Atividade antioxidante e metabolismo fermentativo em plantas de Erythrina crista-galli sob alagamento}

\author{
Cristina Ferreira Larré ${ }^{1 *}$; Caroline Leivas Moraes ${ }^{1}$; Junior Borella ${ }^{1}$; \\ Luciano do Amarante ${ }^{2}$; Sidnei Deuner ${ }^{2}$; José Antonio Peters ${ }^{2}$
}

\begin{abstract}
This study aimed to evaluate the mechanisms of flood tolerance of the root system of Erythrina cristagalli L. plants by measuring the activity of antioxidant enzymes and oxidative stress components in the leaves and roots. Additionally, the activity of fermentation enzymes in the roots was measured. The following two treatments were used: plants with flooded roots, which were maintained at a given water level above the soil surface, and non-flooded plants, which were used as the control. The measurements were performed at 10,20,30,40, and 50 days after treatment. The following parameters were evaluated at each time-point: the activities of superoxide dismutase, catalase and ascorbate peroxidase, the quantification of lipid peroxidation and hydrogen peroxide $\left(\mathrm{H}_{2} \mathrm{O}_{2}\right)$ content in the leaves, roots, and adventitious roots, and the activities of lactate dehydrogenase, pyruvate decarboxylase and alcohol dehydrogenase in both the primary and adventitious roots. There was an increase in the activity of catalase and ascorbate peroxidase in the leaves to maintain stable $\mathrm{H}_{2} \mathrm{O}_{2}$ levels, which reduced lipid peroxidation. In the roots, higher activity of all antioxidant enzymes was observed at up to 30 days of flooding, which favoured both reduced $\mathrm{H}_{2} \mathrm{O}_{2}$ levels and lipid peroxidation. Activity of the fermentation enzymes was observed in the primary roots from the onset of the stress conditions; however, their activity was necessary only in the adventitious roots during the final periods of flooding. In conclusion, E. crista-galli L. depends on adventitious roots and particularly on the use of the fermentation pathway to tolerate flood conditions.
\end{abstract}

Key words: Fabaceae. Hypoxia. Oxidative stress. Riparian forest. Tolerance.

\section{Resumo}

O objetivo deste trabalho foi determinar os mecanismos de tolerância ao alagamento de plantas de Erythrina crista-galli L., por meio da avaliação da atividade de enzimas antioxidantes e fermentativas, assim como dos componentes do estresse oxidativo em folhas e raízes. Plantas oriundas de sementes foram cultivadas em vasos com capacidade para 0,5 litros em casa de vegetação e transferidas para vasos de cinco litros. Foram utilizados dois tratamentos: plantas alagadas nas raízes com a manutenção de uma lâmina de água acima da superfície do solo e plantas não alagadas (controle). As avaliações foram realizadas aos 10, 20, 30, 40 e 50 dias após a indução dos tratamentos. O delineamento experimental utilizado foi em blocos ao acaso e os resultados obtidos submetidos à análise de variância e analisados por

\footnotetext{
${ }^{1}$ Biólogos, Drs. em Fisiologia Vegetal, Programa de pós-graduação em Fisiologia Vegetal, Dept ${ }^{\circ}$ de Botânica, Instituto de Biologia, Universidade Federal de Pelotas, UFPel, Campus Universitário - Capão do Leão, RS, Brasil. E-mail: cristina_larre@yahoo.com. br; caroline.moraes@gmail.com; borellaj@gmail.com

${ }^{2}$ Eng $^{\text {os }}$ Agros $^{\text {os }}$ Profs. Drs., Programa de pós-graduação em Fisiologia Vegetal, Dept ${ }^{\circ}$ de Botânica, Instituto de Biologia, UFPel, Campus Universitário, Capão do Leão, RS, Brasil. E-mail: lucianodoamarante@yahoo.com.br; sdeuner@yahoo.com.br; japeters1@hotmail.com

* Author for correspondence
} 
comparação de médias pelo Teste de Tukey. Em cada período foram avaliadas a atividade de superóxido dismutase, catalase, ascorbato peroxidase, quantificação da peroxidação lipídica e teores de peróxido de hidrogênio em folhas, raízes e raízes adventícias; a atividade das enzimas lactato desidrogenase, piruvato descarboxilase e álcool desidrogenase nas raízes principais e adventícias. Foi verificado um aumento na atividade das enzimas ascorbato peroxidase e catalase nas folhas para manter estáveis os níveis de $\mathrm{H}_{2} \mathrm{O}_{2}$ o que proporcionou redução na peroxidação lipídica. Nas raízes foi verificada uma atuação mais marcante de todas as enzimas antioxidantes até os 30 dias de alagamento, favorecendo a redução nos níveis de $\mathrm{H}_{2} \mathrm{O}_{2}$ e de peroxidação de lipídios. A atividade das enzimas fermentativas foi evidenciada nas raízes principais desde o início do estresse, porém nas raízes adventícias só foi requerida nos períodos finais. Pode-se concluir que a E. crista-galli L., depende das raízes adventícias e, em especial, da utilização da rota fermentativa para tolerar a condição de alagamento.

Palavras-chave: Fabaceae. Estresse oxidativo. Hipoxia. Mata ciliar. Tolerância.

\section{Introduction}

Erythrina crista-galli L. is a medium-sized tree of the family Fabaceae that attracts pollinators such as humming birds (LORENZI, 2009). E. cristagalli L. is a forest species that is native to Brazil, and it is listed as a protected speciesby State Law 9.519 / 92 (Art. 33) in Rio Grande do Sul, because of devastation to its natural habitat and importance in recovering degraded ecosystems and restoring riparian forests.

Riparian forests are important for rivers because they prevent silting, ensure the survival of aquatic and riparian organisms, and maintain water quality. Reduced oxygen $\left(\mathrm{O}_{2}\right)$ availabilityin the soil due to excess water is the primary constraint to the growth and adaptation of riparian species (MEDINA et al., 2009).

Excess water reduces gas diffusion, thereby further reducing $\mathrm{O}_{2}$ availability in the soil and, consequently, compromising plant root systems. This decrease in $\mathrm{O}_{2}$ availability is a signal for abiotic stress that triggers a change in the normal metabolism of the plant (DAT et al., 2004). The ability of species to tolerate and adapt to periods of either submersion or soil flooding can be attributed to morpho-anatomical, physiological, and biochemical adaptation mechanisms (ISHIDA et al., 2002).

Reactive oxygen species (ROS) are continuously produced in chloroplasts, mitochondria, and peroxisomes during normal plant metabolism at extremely controlled levels (APEL; HIRT, 2004). However, this balance can be altered by several factors such as excess water in the roots. The balance between increased ROS production and the ability to rapidly trigger the antioxidant defence system is reflected in the response of the plant to stress and subsequent adaptation and/or tolerance to adverse conditions due to flooding (MITTLER, 2002). Under these conditions, the plant directs its reserves to maintaining active metabolism in organs with preferential growth. The plant also activates the enzymatic antioxidant system by increasing the activity of enzymes such as superoxide dismutase (SOD), catalase (CAT) and ascorbate peroxidase (APX) (APEL; HIRT, 2004). Therefore, the mechanisms that are required to maintain metabolism will determine the level of tolerance to flood conditions for each plant species. Thus, monitoring the activity of antioxidant enzymes can be used as an indicator of oxidative stress in plants.

In addition, to suppress the energy deficit in plants that is caused by flooding, some species redirect their metabolic pathways to ensure adequate ATP production by increasing the rate of carbohydrate fermentation. This is accomplished by increasing the activity of the lactate dehydrogenase (LDH ), pyruvate decarboxylase (PDC) and alcohol dehydrogenase (ADH ) enzymes (DREW, 1997).

The majority of studies on signalling pathways and flood tolerance were performed on plants such 
as rice and Arabidopsis (GRANDIS et al., 2010), and little is currently known regarding the mechanisms involved in the acclimation of forest plant species subjected to flooding stress. Understanding these mechanisms is of great importance and will have a positive impact on elucidating the relationship between the biodiversity of forest species and environmental conditions. Therefore, the knowledge acquired regarding the physiological and biochemical traits of E. crista-galli L. is critical for determining its potential for revitalising riparian forests and restructuring degraded areas.

The objective of this study was to describe the mechanisms used by plants of E. crista-galli L., to tolerate the stress caused by changes in water conditions, by assessing the activity of antioxidant enzymes, components of oxidative stress and activity of fermentative enzymes.

\section{Materials and Methods}

\section{Plant material and experimental conditions}

E. crista-galli L. seeds, previously scarified and disinfested with $5 \%$ sodium hypochlorite solution, were sown in 0.5 -L plastic containers containing commercial substrate (Plantmax $\left.{ }^{\circledR}\right)$. One month after sowing, the seedlings were transplanted to perforated $5-\mathrm{L}$ plastic containers containing a mixture of soil (albaqualf type) and washed sand $(1: 1)$ and transferred to the greenhouse from Federal University of Pelotas, located at $31^{\circ} 52^{\prime} 00$ " 5 latitude (S) and $52^{\circ} 21^{\prime} 24^{\prime \prime}$ longitude (W) and kept under natural light and temperature conditions. The evaluation was done between the months october and november of 2011 with average temperature of 17.8 and $20.6{ }^{\circ} \mathrm{C}$, respectively (EAPEL, 2015). The plants were maintained in these containers for three months prior to treatment. Seven days after the onset of emergence, $0.2 \mathrm{~L}$ half-strength Hoagland and Arnon nutrient solution (HOAGLAND; ARNON, 1938) was administered to all plants, and this treatment was repeated every two days throughout the experimental period.

\section{Treatment administration}

The following two treatments were used: flooded plants with a constant water level at least three $\mathrm{cm}$ above the soil surface throughout the experiment and non-flooded plants as the control. The plants were irrigated daily, and the soil was maintained near field capacity. The evaluations were conducted at 10,20, 30,40 , and 50 days after the beginning of treatment. The experimental design was a randomised block with two treatments, five evaluation periods, and four replicates. Each replicate consisted of two plants.

For evaluations leaves were fully expanded, the fourth node, starting from the apex of the shoot, collected between 8 and 9 am. The material was packed in aluminum foil bags, previously identified and stored in ultra-freezer at $-70^{\circ} \mathrm{C}$ until analysis.

\section{Antioxidant enzymes}

The activity of the antioxidant enzymes, SOD (EC 1.15.1.1), APX (EC 1.11.1.11), and CAT (EC 1.11.1.6), was assessed in the leaves, principal roots (first-order lateral roots originating directly from the primary root), and adventitious roots. The enzymatic extract was obtained by macerating approximately $500 \mathrm{mg}$ plant material in liquid $\mathrm{N}_{2}$ and 20\% polyvinylpolypyrrolidone (PVPP) with an added extraction medium consisting of $100 \mathrm{mM}$ potassium phosphate buffer ( $\mathrm{pH}$ 7.8), 0.1 mM EDTA, and $20 \mathrm{mM}$ ascorbic acid. After centrifugation, the supernatant from the same extract was used to determine the activity of the expressed enzymes based on the protein content that was quantified by the Bradford method (BRADFORD, 1976).

SOD activity was evaluated as the enzymatic inhibition of nitroblue tetrazolium (NBT) photoreduction (GIANNOPOLITIS; RIES, 1977) in a reaction medium consisting of $50 \mathrm{mM}$ potassium phosphate buffer ( $\mathrm{pH} 7.8$ ), $14 \mathrm{mM}$ methionine, $75 \mu \mathrm{M}$ NBT, $0.1 \mu \mathrm{M}$ EDTA, and $2 \mu \mathrm{M}$ riboflavin. The readings were performed at $560 \mathrm{~nm}$. One 
SOD unit corresponded to the amount of enzyme causing 50\% inhibition of NBT photoreduction under the experimental conditions. APX activity was determined according to the method of Nakano and Asada (1981) by monitoring the oxidation rate of ascorbate (ASA) at $290 \mathrm{~nm}$. The decrease in absorbance was monitored for a 1.5-minute period at $28^{\circ} \mathrm{C}$, and the activity was calculated using a molar extinction coefficient of $2.8 \mathrm{molL}^{-1} \mathrm{~cm}^{-1}$. CAT activity was determined according to the method of Azevedo et al. (1998). CAT activity was monitored by the decrease in absorbance at $240 \mathrm{~nm}$ during a 1.5 -minute period at $28^{\circ} \mathrm{C}$, and the activity was calculated using a molar extinction coefficient of $39.4 \mathrm{~mol} \mathrm{~L}^{-1} \mathrm{~cm}^{-1}$.

\section{Lipid peroxidation and hydrogen peroxide}

Lipid peroxidation and hydrogen peroxide $\left(\mathrm{H}_{2} \mathrm{O}_{2}\right)$ content were quantified by macerating approximately $500 \mathrm{mg}$ of fresh mass (FM) of leaves, roots, and adventitious roots in liquid $\mathrm{N}_{2}$ with added 20\% PVPP and $2 \mathrm{~mL}$ of extraction solution containing $0.1 \%$ trichloroacetic acid (TCA). The material was homogenised and centrifuged at $12,000 \mathrm{~g}$ for $20 \mathrm{~min}$, and the resulting supernatant was transferred to 2-mL microcentrifuge tubes.

Lipid peroxidation was determined by the quantification of thiobarbituric acid-reactive species (TBARS) as described by Cakmak and Horst (1991) with some modifications. The measurements were performed in a spectrophotometer at $535 \mathrm{~nm}$ and $600 \mathrm{~nm}$. Thiobarbituric acid (TBA) forms reddishcoloured complexes with low-molecular-weight aldehydes such as malondialdehyde (MDA), which is a secondary product of the peroxidation process. The concentration of the MDA/TBA complex was calculated by the following equation: $[\mathrm{MDA}]=\left(\mathrm{A}_{535}\right.$ $\left.-\mathrm{A}_{600}\right) /(\xi . b)$, where $\xi$ is the extinction coefficient $=1.56 \times 10^{-5} \mathrm{~cm}^{-1}$ and $\mathrm{b}$ is the optical length $=1$. Peroxidation was expressed as $\mu \mathrm{mol} \mathrm{MDA} \mathrm{g}^{-1} \mathrm{FM}$.

$\mathrm{H}_{2} \mathrm{O}_{2}$ was quantified according to the method of Velikova et al. (2000) with measurements performed using a spectrophotometer at $390 \mathrm{~nm}$. The values were expressed as $\mu \mathrm{mol} \mathrm{H}_{2} \mathrm{O}_{2} \mathrm{~g}^{-1} \mathrm{FM}$.

\section{Anaerobic enzymes}

The anaerobic metabolism enzymes, $\mathrm{ADH}$ (EC 1.1.1.1), LDH (EC 1.1.1.27), and PDC (EC 4.1.1.1), were extracted by macerating $500 \mathrm{mg}$ of plant tissue in liquid $\mathrm{N}_{2}$ containing 5\% PVPP with extraction buffer consisting of $50 \mathrm{mM}$ Tris- $\mathrm{HCl}(\mathrm{pH} 7.5)$ and $1 \mathrm{mM}$ dithiothreitol (DTT). After homogenisation, the extracts were centrifuged at $10,000 \mathrm{~g}$ at $4^{\circ} \mathrm{C}$ for $20 \mathrm{~min}$. A $2.5-\mathrm{mL}$ aliquot was removed from the centrifuged supernatant for desalination by exclusion chromatography on a Sephadex G-25 $\mathrm{M}$ column (PD-10). This was used to determine the expressed enzyme activity based on the total soluble protein content quantified by the Bradford method (BRADFORD, 1976).

The activity of $\mathrm{ADH}$ was evaluated at $30^{\circ} \mathrm{C}$ using the desalinated extract, $50 \mathrm{mM}$ potassium phosphate buffer ( $\mathrm{pH} 7.0$ ), $0.2 \mathrm{mM} \mathrm{NADH}$, and 5 $\mathrm{mM}$ acetaldehyde. NADH oxidation was monitored at $340 \mathrm{~nm}$ for $2 \mathrm{~min}$, and the enzyme activity was expressed as the amount of $\mathrm{NAD}^{+}$produced per minute of incubation per mg of protein. LDH activity was evaluated at $30^{\circ} \mathrm{C}$ using the desalinated extract, $50 \mathrm{mM}$ potassium phosphate buffer $(\mathrm{pH} 7.0), 0.2$ $\mathrm{mM}$ NADH, $3 \mu \mathrm{M}$ potassium cyanide $(\mathrm{KCN}), 4$ $\mathrm{mM}$ methylpyrazol, and $10 \mathrm{mM}$ sodium pyruvate. $\mathrm{NADH}$ oxidation was monitored at $340 \mathrm{~nm}$ for 2 min, and the enzyme activity was expressed as the amount of $\mathrm{NAD}^{+}$produced per minute of incubation per mg of protein. PDC activity was evaluated at $30^{\circ} \mathrm{C}$ using the desalinated extract, $50 \mathrm{mM}$ MES$\mathrm{NaOH}$ buffer (pH 6.5), $0.2 \mathrm{mM} \mathrm{NADH}, 1 \mathrm{mM}$ $\mathrm{MgCl}_{2}, 0.5 \mathrm{mM}$ thiamine pyrophosphate (TPP), 20 $\mathrm{m}$ Moxamic acid, ADH (10U), and $10 \mathrm{mM}$ sodium pyruvate. The reaction was monitored at $340 \mathrm{~nm}$ for 2 min. Enzyme activity was expressed as the amount of $\mathrm{NAD}^{+}$produced per minute of incubation per mg of protein. 


\section{Statistical analysis}

The results obtained were subjected to an analysis of variance (ANOVA) and analysed by comparing the means with the Tukey test at a 5\% significance level using the WinStat software (MACHADO; CONCEIÇÃO, 2007).

\section{Results}

Activity of antioxidant enzymes, $\mathrm{H}_{2} \mathrm{O}_{2}$, and lipid peroxidation

SOD activity in the leaves was not significantly different between treatments, although the flooded plants exhibited peak SOD activity at 40 days and returned to near initial values at the end of the evaluation period (Figure1A). By contrast, there was a significant difference in APX activity between treatments beginning at the first evaluation until 40 days, with higher APX activity values for the flooded plants. The flooded plants exhibited peak APX activity at 30 days of flooding, representing an increase of approximately 100\% compared to the control plants. There was a gradual decrease in APX activity beginning at this time, with similar values for APX activity for the two treatments at the 50-day time-point (Figure1B). The CAT enzyme exhibited a similar behaviour to SOD, and there was no significant difference between treatments during the periods evaluated; however, CAT activity peaked for the flooded plants at 30 days with a $25 \%$ increase relative to the control plants (Figure 1C).

There was significant difference between the treatments for $\mathrm{H}_{2} \mathrm{O}_{2}$ content (Figure1D). The flooded plants exhibited higher $\mathrm{H}_{2} \mathrm{O}_{2}$ values than the control plants during the period evaluated, and the difference was more pronounced at 10 days with a $35 \%$ higher $\mathrm{H}_{2} \mathrm{O}_{2}$ contentin the flooded plants (Figure1D). The level of lipid peroxidation decreased for both treatments during the periods evaluated. However, the flooded plants exhibited a higher level of lipid peroxidation than the control plants throughout the experiment, averaging 60\% higher (Figure1E).

In contrast to the leaves, SOD activity in the roots was significantly different between the treatments. For the primary root, the values obtained indicated that SOD activity increased in the flooded plants, reaching $80 \%$ and $220 \%$ higher values than the control plants at 20 and 30 days, respectively. There a was gradual decrease in SOD activity during the last periods evaluated (40 and 50 days); however, values $70 \%$ higher than the first period (10days) and $35 \%$ higher than the control plants remained evident at 50 days (Figure 2A). For APX, there was a significant difference between the treatments at 20 and 30 days after treatment administration, and the flooded plants exhibited $25 \%$ and $40 \%$ higher APX activity than the control plants, respectively. However, APX activity began decreasing at 30 days, reaching values similar the control at 40 days and 50 days (Figure 2B). CAT displayed a similar behaviour to APX; however, there was a significant difference between the treatments at 30 days and 40 days, with $43 \%$ and $30 \%$ higher values for the flooded plants, respectively. CAT activity significantly decreased for both treatments beginning during this period, and the values for both treatments were the same during the last evaluation at 50 days (Figure 2C). 
Figure 1. SOD (A), APX (B) and CAT (C) enzyme activities and $\mathrm{H}_{2} \mathrm{O}_{2}$ (D) and MDA (E) content in the leaves of E.crista-galliL. plants subjected to flooding stress $(\square)$ and control plants $(\square)$. The bars represent the standard error of the mean from four replicates. *Represents a significant difference at a $5 \%$ significance level as determined by the Tukey test.
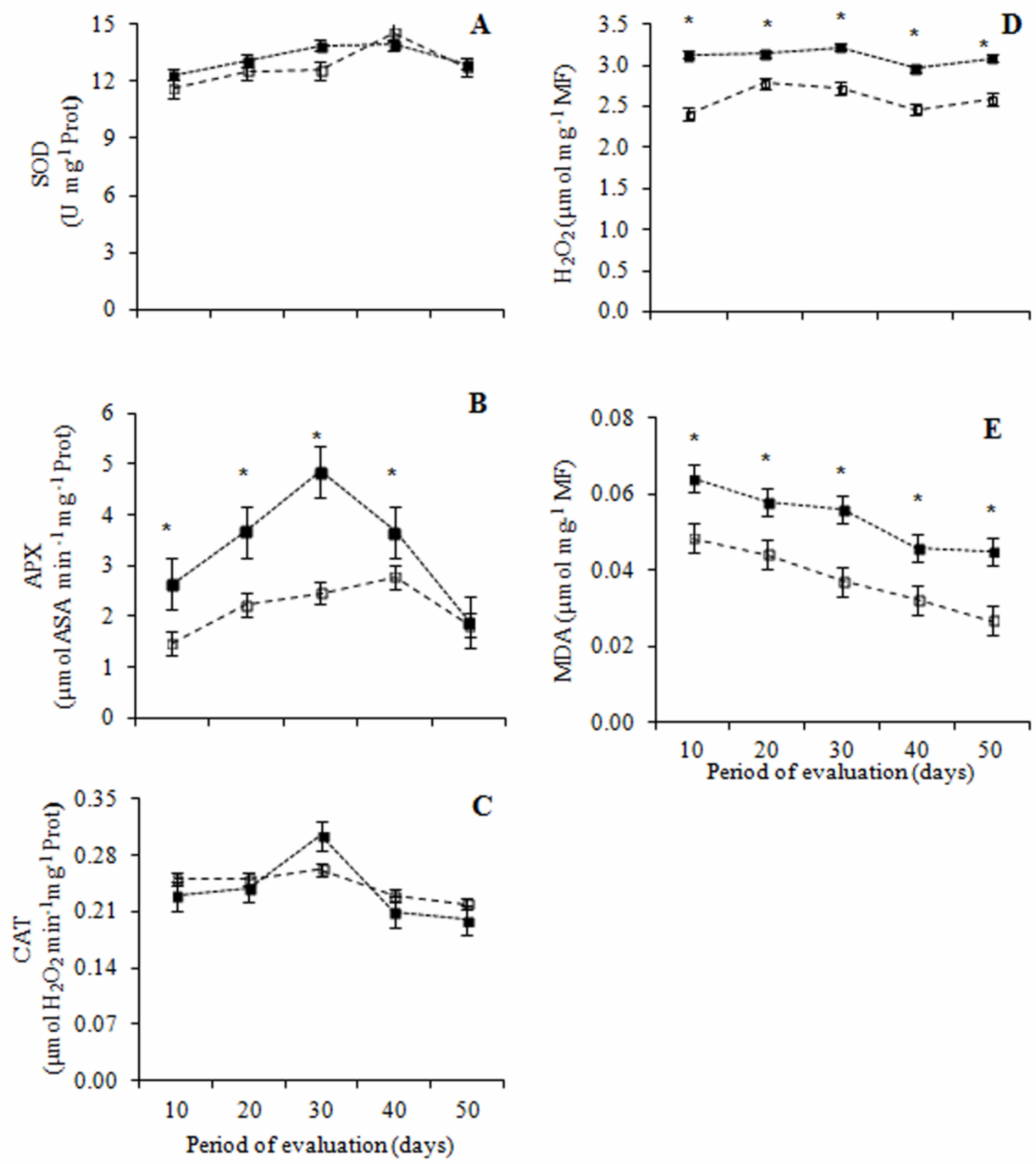
Figure 2. $\mathrm{SOD}(\mathrm{A}), \mathrm{APX}(\mathrm{B})$, and CAT (C) enzyme activities and $\mathrm{H}_{2} \mathrm{O}_{2}(\mathrm{D})$ and MDA (E) content in the primary roots of E. crista-galli L. plants subjected to flooding stress $(\square)$ and control plants $(\square)$. The bars represent the standard error of the mean from four replicates. *Represents a significant difference at a $5 \%$ significance level as determined by the Tukey test.
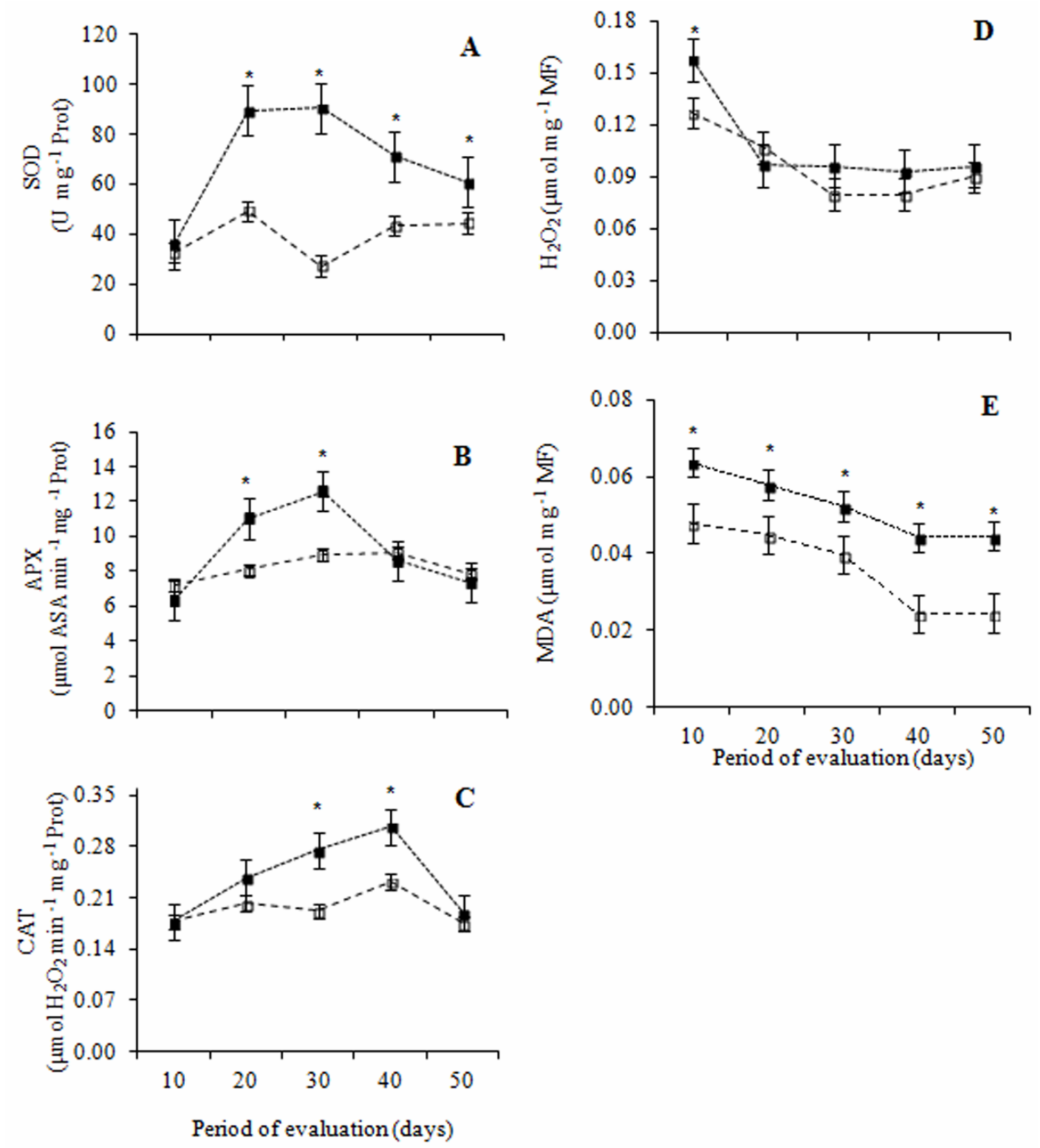

The results obtained for $\mathrm{H}_{2} \mathrm{O}_{2}$ content quantification in the root tissues showed higher values at 10 days, and during this period, the flooded plants exhibited significantly higher levels of $\mathrm{H}_{2} \mathrm{O}_{2}$ than the control plants. Beginning during this period, the $\mathrm{H}_{2} \mathrm{O}_{2}$ levels decreased, which did

not differ between the treatments (Figure 2D). Lipid peroxidation in the roots was similar to that observed in leaves with significant differences between the treatments during all periods evaluated, and the flooded plants exhibited the highest lipid peroxidation values (Figure 2E). 
For the flooding responses of the primary roots and adventitious roots, SOD activity was significantly different for all periods evaluated. The SOD activity values obtained for the primary roots increased and were considerably higher than the adventitious roots, reaching values $880 \%$ higher at 20 days, and this difference decreased to $55 \%$ at 50 days (Figure 3A). APX activity was similar to SOD activity, with higher activity in the primary roots compared to the adventitious roots, and this difference varied by $380 \%, 350 \%, 220 \%$, and $15 \%$ at 20,30, 40, and 50 days, respectively (Figure 3B). For CAT activity, there was a significant difference between the primary and adventitious roots for the periods of 10 to 40days. During this time, CAT activity increased and was significantly higher in the primary roots (Figure3C). The CAT activity values for both tissues were not different at 50 days.

Figure 3. SOD (A), APX (B), and CAT (C) enzyme activities and $\mathrm{H}_{2} \mathrm{O}_{2}(\mathrm{D})$ and MDA (E) content in the primary roots ( $\square$ ) and adventitious roots ( $\square$ ) of E. crista-galli L. plants subjected to flooding stress. The bars represent the standard error of the mean from four replicates. *Represents a significant difference at a $5 \%$ significance level as determined by the Tukey test.
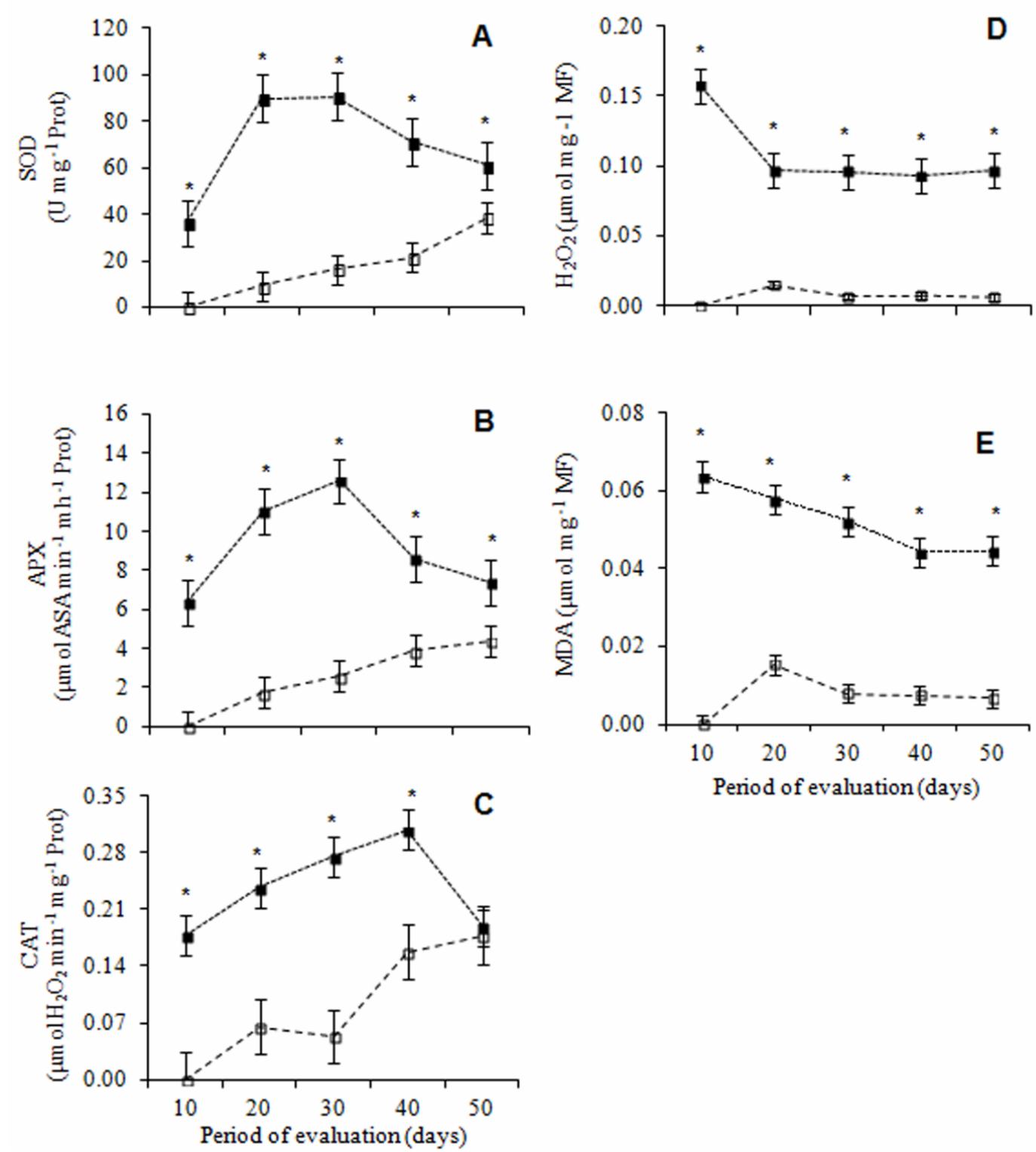
For the lipid peroxidation level (Figure 3D) and free $\mathrm{H}_{2} \mathrm{O}_{2}$ content in cells, there were significant differences between the primary and adventitious roots (Figure 3E) with considerably lower values for both lipid peroxidation and free $\mathrm{H}_{2} \mathrm{O}_{2}$ levels in the adventitious roots compared to the primary roots throughout the experimental period.

\section{Activity of anaerobic enzymes}

The activity of LDH, PDC and ADH was low and stable in the primary roots of the control plants throughout the experimental period. However, the activity of these enzymes significantly increased in the flooded plants, with a significant difference between both treatments during all periods evaluated. There was a $160 \%$ increase in $\mathrm{LDH}$ activity in the flooded roots after 20 days compared to 10 days and an increase of $380 \%$ compared to the control plants. This difference in LDH activity decreased at 30 days and remained constant until the end of the experiment (50 days) when the values were $170 \%$ higher than the control plants (Figure 4A). The same response was observed for PDC activity, although the PDC activity in flooded roots was more markedly different between the treatments compared to LDH during all periods evaluated. PDC activity was $880 \%$ higher than the control plants at 10 days, and this difference was also observed at the end of the experiment (Figure 4B).
Similarly, ADH exhibited increasing activity in the flooded roots throughout the periods evaluated and was significantly different between treatments. At 10 days of treatment, the flooded plants exhibited ADH activity values 18 times higher than the control plants, where as the ADH activity in the flooded plants was up to 23 times higher than the control plants at 40 days (Figure 4C).

For the fermentation enzymes, there was a significant difference in LDH activity between the adventitious and primary roots of flooded plants (Figure 5A). LDH activity was 17 times higher in the primary roots than adventitious roots at 20 days. However, LDH activity increased in the adventitious roots as a function of flooding duration, reaching levels similar to the primary roots at the end of the experiment (Figure 5A). Similarly, PDC and $\mathrm{ADH}$ were also significantly different between both treatments. PDC activity only increased in the primary roots after 40 days and increased by $300 \%$ after 50 days compared to the 40-day time-point (Figure 5B). However, PDC activity was 65\% lower in the adventitious roots compared to the primary roots at the end of the evaluation. ADH was also significantly different between treatments at all periods evaluated, and at 50 days, $\mathrm{ADH}$ activity was 10 times higher than during the previous period at 40 days. ADH activity was 36 times higher in primary roots than adventitious roots after 50 days of flooding (Figure 5C). 
Figure 4. $\mathrm{LDH}(\mathrm{A}), \mathrm{PDC}(\mathrm{B})$ and $\mathrm{ADH}(\mathrm{C})$ enzyme activities in the primary root sof E.crista-galliL. plants subjected to flooding stress ( $\square$ ) and control plants (口). The bars represent the standard error of the mean from four replicates. *Represents a significant difference at a $5 \%$ significance level as determined by the Tukey test.
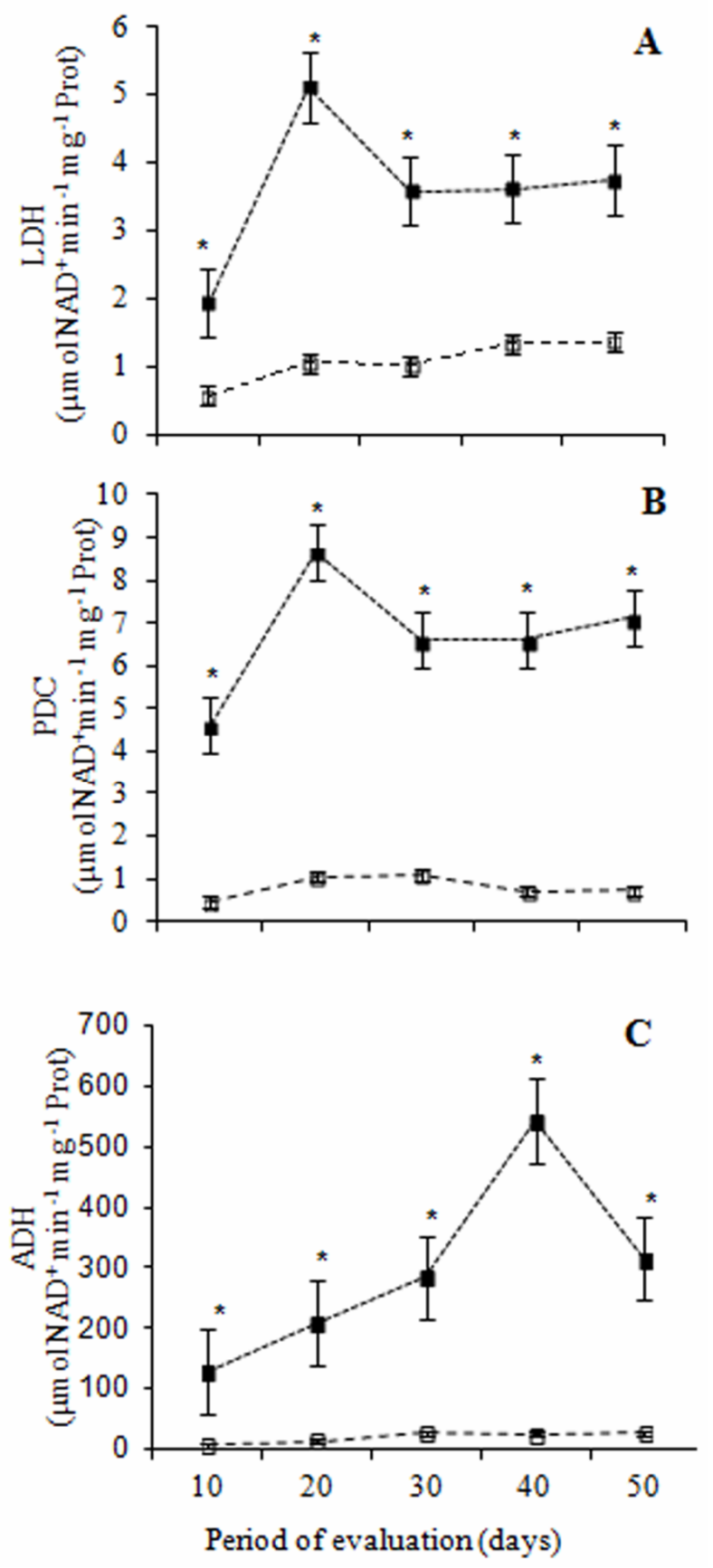

Figure 5. LDH (A), PDC (B), and ADH (C) enzyme activities in the primary roots ( $\square)$ and adventitious roots () of E. crista-galli L. plants subjected to flooding stress. The bars represent the standard error of the mean from four replicates. *Represents a significant difference at a $5 \%$ significance level as determined by the Tukey test.
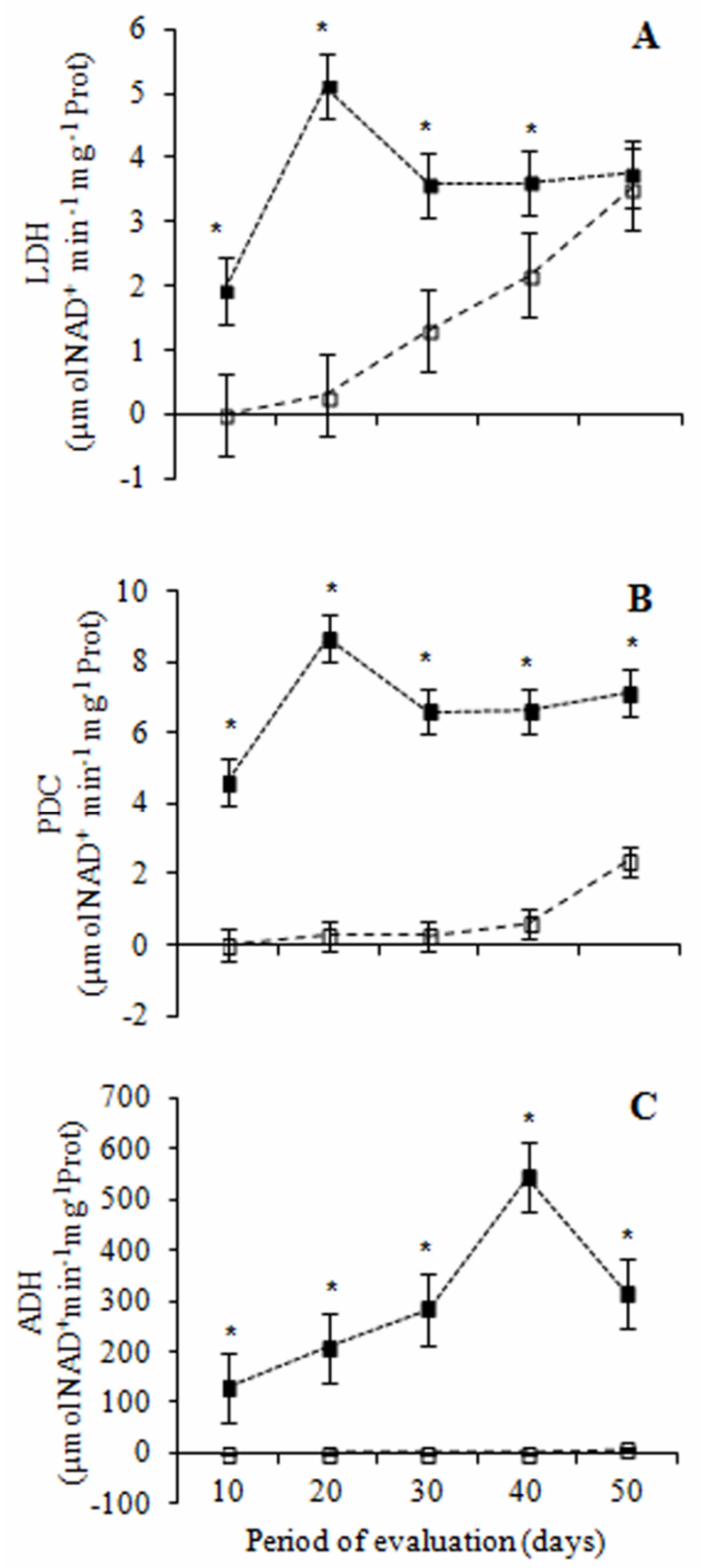


\section{Discussion}

During recent years, cellular oxidative damage caused by plant exposure to flooding has garnered increasing attention. Cellular oxidative damage is a condition in which oxidative phosphorylation is either reduced or stopped due to $\mathrm{O}_{2}$ deficiency (BLOKINA et al., 2003). In plants under hypoxic or anoxic soil conditions, there is increased ROS production, which includes superoxide radicals $\left(\mathrm{O}_{2}{ }^{\bullet-}\right.$ ), singlet oxygen $\left({ }^{1} \mathrm{O}_{2}\right), \mathrm{H}_{2} \mathrm{O}_{2}$, and hydroxyl radicals $\left(\mathrm{OH}^{\bullet}\right)$. These ROS species can cause oxidative damage in various parts of the plant (VERMA; DUBEY, 2003). The reaction of these radicals with lipids triggers a cascade of reactions, culminating in the lipid peroxidation of membranes. Altered membrane structure and function as a result of lipid peroxidation have also been characterised under flooding stress and may negatively affect cellular functioning (MITTLER et al., 2004).

In E.crista-galli L. leaf tissues, SOD activity remained unaltered compared to the control plants (Figure 1A). By contrast, APX and CAT activity increased until 30 days of flooding (Figures $1 \mathrm{~B}$ and 1C). SOD is considered the first line of antioxidant defence. It dismutates $\mathrm{O}^{\bullet-}$ that is formed through the deviation of electrons to molecular $\mathrm{O}_{2}$, resulting in the production of $\mathrm{H}_{2} \mathrm{O}_{2}$, and SOD is present in various cellular compartments (MITTLER, 2002). Increased APX activity explains the maintenance of $\mathrm{H}_{2} \mathrm{O}_{2}$ levels as a stress signal because APX has a low $\mathrm{Km}$ for this substrate, which is characteristic of a higher affinity than CAT for $\mathrm{H}_{2} \mathrm{O}_{2}$. Because $\mathrm{H}_{2} \mathrm{O}_{2}$ is easily diffused across cell membranes, it acts as a signalling molecule in plants by activating the expression of genes that are related to the stress response (SCANDALIOS, 2002). When $\mathrm{H}_{2} \mathrm{O}_{2}$ levels exceed the detoxification capacity of APX, CAT activity is stimulated.

Previous studies have shown that this species with damage to the photosynthetic apparatus was reduced by changes in the energy flow in PS II by an increase in the dissipation assessed by chlorophyll fluorescence transient (LARRÉ et al., 2013). Thus, results obtained for the activity of the antioxidant enzymes in E.crista-galli L. leaves (Figure 1), suggest that there was as increase in the photorespiratory cycle due to stomatal closure. Photorespiration may be an alternative in $\mathrm{C}_{3}$ plants to help consume a considerable portion of the electron flow when $\mathrm{CO}_{2}$ availability is limited in chloroplasts (MEDINA et al., 2009). However, this process causes increased $\mathrm{H}_{2} \mathrm{O}_{2}$ content in peroxisomes, which may explain the increased CAT and APX activities during this period (Figures 1C and $\mathrm{B}$ ). The reduction in CAT and APX activities during the final periods of evaluation coincides with the reestablishment of growth due to species adaptation to flooding via other mechanisms, such as the formation of adventitious roots (LARRÉ et al., 2013).

Increased APX activity coincides with the maintenance of stable $\mathrm{H}_{2} \mathrm{O}_{2}$ levels even at values higher than those observed in the control plants (Figure 1D). Inregulating $\mathrm{H}_{2} \mathrm{O}_{2}$ levels, it is possible to control the level of lipid peroxidation, as demonstrated by the efficient use of the antioxidant defence system in cockspur coral tree leaves (Figure 1E).

The activity of the root antioxidant enzymes exhibited different responses compared to the aerial parts of the plant because the roots were directly affected by the hydric conditions. Increased SOD activity at 20 and 30 days of flooding is characterised by reduced molecular $\mathrm{O}_{2}$ in the root cells because this is the final electron acceptor in the mitochondrial electron transport chain. Mitochondria are extremely sensitive to changes in environmental $\mathrm{O}_{2}$ levels because they are the main sites of $\mathrm{O}_{2}$ consumption and $\mathrm{O}_{2}$ consumption can lead to increased ROS production as a by-product of respiratory metabolism under hypoxic conditions (DAT et al., 2004).

SOD is the first enzyme to act in the enzymatic antioxidant defence system, and the results of 
the SOD activity assay (Figure 2A) explain the increased APX and CAT activities (Figures 2B and $3 \mathrm{C}$, respectively) during this same period. This is because increased $\mathrm{O}^{\bullet}{ }_{2}$ production activates SOD and directly reflects the increased free $\mathrm{H}_{2} \mathrm{O}_{2}$ concentration, thereby requiring stimulation of the enzymes that are responsible for degrading this molecule. The ability to maintain high levels of SOD, CAT and APX activities under environmental stress conditions is essential for the balance between ROS formation and removal within the intracellular environment (MATÉS, 2000).

Membrane polyunsaturated fatty acids are highly susceptible to attack by $\mathrm{OH}^{\bullet}$. Therefore, lipid peroxidation mediated by the action of free radicals can be used as an indicator of oxidative stress (VERMA; DUBEY, 2003). In this study, the efficient action of antioxidant enzymes in the roots prevented the $\mathrm{H}_{2} \mathrm{O}_{2}$ levels from increasing and reduced the peroxidation of membrane lipids as determined by MDA formation (Figures 2D and E).

After 10 days of treatment, the flooded plants formed adventitious roots. During this period, the adventitious roots remained in contact with the water level surface despite their small size. This condition favoured atmospheric $\mathrm{O}_{2}$ permeability through root tissues, which explains the difference in antioxidant enzyme activities (CAT, APX and SOD) when the primary and adventitious roots were evaluated (Figure3). However, the duration of exposure of the adventitious roots to the hypoxic substrate provided a similar response to the primary roots, and the activity of all enzymes increased with increased exposure to stress. This efficient use of the enzymatic antioxidant system in adventitious roots controlled ROS production, which is evidenced by low $\mathrm{H}_{2} \mathrm{O}_{2}$ levels in the adventitious roots (Figure $3 \mathrm{E})$. This limited the formation of lipid peroxides, there by preventing damage to the cell membranes in these roots (Figure3D).

Plants can only survive soil hypoxia or anoxia if they maintain ATP production and recycle reducing power. Metabolic adaptation is associated with an increased fermentation rate as a function of the increased activity of anaerobic pathway enzymes, such as LDH, PDC and ADH (MORAES et al., 2001). These statements are supported by the results of the present study on E. crista-galli L. plants.

In this study, LDH activity increased at 20 days, and although this activity decreased during subsequent periods, LDH activity remained higher than the control plants (Figure 4A). In Digitaria suazilandensis grass, hypoxic treatment reduced the activity of LDH in both the root and leaf without affecting plant survival (MORAES et al., 2001) suggesting that species tolerance is associated with other mechanisms.

The decrease in $\mathrm{pH}$ is controlled by the balance between lactate and ethanol production and, consequently, the balance between $\mathrm{LDH}$ and ADH activities. Altered $\mathrm{pH}$ resulting from cytosolic acidification due to lactic acid formation by $\mathrm{LDH}$ acts as a signalling mechanism in plants under flood conditions. The accumulation of lactate under low $\mathrm{O}_{2}$ concentrations occurs before ethanol production in the root cells. This dropin $\mathrm{pH}$ favours the catalytic activity of PDC, which is responsible for modulating lactate conversion into ethanol under hypoxic or anoxic conditions (GRANDIS et al., 2010). This explains the results obtained in this study regarding the activity of these enzymes (Figures 4A and B).

In E.crista-galli L. plants, the highly altered activity ofADH (Figure 4C) compared tonon-flooded plants was observed. ADH exhibited increasing levels with increasing exposure to $\mathrm{O}_{2}$ deficit, suggesting that in addition to other mechanisms, this species requires the rapid and continuous use of the fermentation pathway as an alternative for maintaining metabolism, regenerating reducing power and producing ATP when subjected to excess water in the roots.

The activity of the fermentation enzymes in the adventitious roots (Figure 5) was similar to the antioxidant enzymes. In the adventitious roots, 
the use of the fermentation pathway was gradually required as a function of the exposure duration, suggesting that the duration and degree of root submersion directly affected the need to increase the activity of fermentation enzymes to endure, together with primary roots, the stress caused by flooding and to maintain ATP production and plant metabolism. The formation of the adventitious roots and use of the fermentation pathway in these roots likely contributed to the reduced activity of these enzymes in the primary roots during the final period of evaluation.

High levels of ADH activity have been associated with flood tolerance in plants (MORAES et al., 2001). In Echinochloacrus-galli (L.) Beauvunder flood conditions, the activities of the enzymes involved in anaerobic metabolism increased from 1.5 to 30 times compared to the aerobic conditions (FUKAO et al., 2003). ADH activity increased in Euterpe oleracea Mart. after two days of either total or partial flooding (GONÇALVES et al., 2010).

For flood-tolerant species, there is no evidence in the literature that $\mathrm{LDH}$ and $\mathrm{ADH}$ activities are limiting for survival of these plants under either hypoxic or anoxic conditions. However, when studying the alterations in gene expression patterns in Arabidopsis plants under flood conditions, Klok et al. (2002) defined some gene classes that are more affected by these conditions, including genes involved in ethanol metabolism, which could characterise a pre-adaptive condition because it allows for continued ATP production (VISSER; VOESENEK, 2004).

\section{Conclusions}

Flooding during the study period do not jeopardise the E. crista-galli L. plants because they quickly activated the enzymatic antioxidant defence system, thereby reducing oxidative damage. Similarly, E. crista-galli L. is able to use the fermentation pathway as an alternative for maintaining energy production under hypoxic conditions.
Formation of adventitious roots is the most evident morphological strategy for plant survival under flood conditions and allows the plants to metabolically adjust, slowly and continuously, throughout the stress period.

\section{References}

APEL, K.; HIRT, H. Reactive oxygen species: metabolism, oxidative stress and signal transduction. Annual Review Plant Biology, Palo Alto, v. 55, n. 1, p. 373-99, 2004.

AZEVEDO, R. A.; ALAS, R. M.; SMITH, R. J.; LEA, P. J. Response from elevated carbon dioxide to air and ozone fumigation in leaves and roots of wild type and a catalase-deficient mutant of barley. Physiologia Plantarum, Copenhagem, v. 104, n. 2, p. 280-292, 1998.

BLOKINA, O.; VIROLAINEM, E.; FAGERSTEDT, K. V. Antioxidants, oxidative damage and oxigen deprivation stress: a review. Annals of Botany, London, v. 91, n. 2, p. 179-194, 2003.

BRADFORD, M. M. A rapid and sensitive method for the quantitation of microgram quantities of protein utilizing the principle of protein-dye binding. Analytical Biochemestry, New York, v. 72, n. 1-2, p. 48-254, 1976.

CAKMAK, I.; HORST, W. J. Effect of aluminium on lipid peroxidation, superoxide dismutase, catalase, and peroxidase activities in root tips of soybean (Glycine max). Physiologia Plantarum, Copenhagem, v. 83, n. 3, p. 463-468, 1991.

DAT, J. F.; CAPELLI, N.; FOLZER, H.; BOURGEADE, P.; BADOT, P. M. Sensing and signaling during plant flooding. Plant Physiology and Biochemistry, Bari, v. 42, n. 4, p. 273-282, 2004.

DREW, M. C. Oxigen deficiency and root metabolism: injury and acclimatation under hypoxia and anoxia. Annual Review Plant Physiology Plant Molecular Biology, Palo Alto, v. 48, n. 1, p. 223-250, 1997.

ESTAÇÃO AGROCLIMATOLÓGICA DE PELOTAS - EAPEL. Dados meteorológicos de Pelotas em tempo real. Pelotas: EMBRAPA, 2015. Disponível em: <http:// agromet.cpact.embrapa.br/>. Acesso em: 28 out. 2015.

FUKAO, T.; KENNEDY, R. A.; YAMASUE, Y.; RUMPHO, M. E. Genetic and biochemical analysis of anaerobically-induced enzymes during seed germination of Echinochloa crus-galli varieties tolerant and intolerant of anoxia. Journal Experimental Botany, Lancaster, v. 54, n. 386, p. 1421-1429, 2003. 
GIANNOPOLITIS, C. N.; RIES, S. K. Superoxide dismutases. I. Occurrence in higher plants. Plant Physiology, Rockville, v. 59, n. 2, p. 309-314, 1977.

GONÇALVES, J. F. C.; LIMA, R. B. S.; FERNANDES, A. V.; BORGES, E. E. L.; BUCKERIDGE, M. S. Physiological and biochemical characterization of the assai palm (Euterpe oleracea mart.) during seed germination and seedling growth under aerobic and anaerobic conditions. Revista Árvore, Viçosa, MG, v. 34, n. 6, p. 1045-1053, 2010.

GRANDIS, A.; GODOI, S.; BUCKERIDGE, M. S. Respostas fisiológicas de plantas amazônicas de regiões alagadas à mudanças climáticas globais. Brazilian Journal of Botany, São Paulo, v. 33, n. 1, p. 1-12, 2010.

HOAGLAND, D. R.; ARNON, D. The water culture method for growing plants without soil. Berkeley: University of California College of Agriculture, Agricultural Experimental Station, 1938. 39 p.

ISHIDA, F.; OLIVEIRA, L. E. M.; CARVALHO, C. J. R.; ALVES, J. D. Efeitos da inundação parcial e total sobre o crescimento, teor de clorofila e fluorescência de Setaria anceps e Paspalum repens. Cienciae Agrotecnologia, Lavras, v. 26, n. 6, p. 1152-1159, 2002.

KLOK, E. J.; WILSON, I. W.; WILSON, D.; CHAPMAN, S. C.; EWING, R. M.; SOMERVILLE, S. C.; PEACOCK, W. J.; DENNIS, E. S. Expression profile analysis of the low-oxigen response in Arabdopsis root cultures. Plant Cell, Waterbury, v. 14, n. 10, p. 2481-2494, 2002.

LARRÉ, C. F.; FERNANDO, J. A.; MARINI, P.; BACARIN, M. A.; PETERS, J. A. Growth and chlorophyll a fluorescence in Erythrina crista-galli L. plants under flooding conditions. Acta Physiologiae Plantarum, Poland, v. 35, n. 5, p. 1463-1471, 2013.

LORENZI, H. Árvores brasileiras: manual de identificação e cultivo de plantas arbóreas nativas do Brasil. São Paulo: Instituto Plantarum, 2009. v. 3, 384 p.

MACHAdO, A. A.; CONCEIÇÃO, A. R. Programa estatístico WinStat: sistema de análise estatística para Windows versão 1.0. Pelotas: UFPel, 2007.

MATÉS, J. M. Effects of antioxidant enzymes in the molecular control of reactive oxygen species toxicology. Toxicology, Hamburg, v. 153, n. 1-3, p. 83-104, 2000.
MEDINA, C. L.; SANCHES, M. C.; TUCCI, M. L. S.; SOUZA, C. A. F.; CUZZUOL, G. R. F.; JOLY, C. A. Erythrina speciosa (Leguminosae-Papilionoideae) under soil water saturation: morphophysiological and growth responses. Annals of Botany, London, v. 104, n. 4, p. 671680, 2009.

MITTLER, R. Oxidative stress, antioxidants and stress tolerance. Trends in Plant Science, Oxford, v. 7, n. 9, p. 405-410, 2002.

MITTLER, R.; VANDERAUWERA, S.; GOLLERY, M.; VAN BREUSEGEM, F. Reactive oxygen gene network of plants. Trends Plant Science, Oxford, v. 9, n. 10, p. 490-498, 2004.

MORAES, M. G.; ALVES, J. D.; OLIVEIRA, L. E. M.; VITORINO, P. F. P. G.; MAGALHÃES, M. M. Caracterização do crescimento e da atividade das desidrogenases alcoólica e lática em seis espécies herbáceas sob condição de hipoxia. Ciência e Agrotecnologia, Lavras, v. 25, n. 1, p. 86-95, 2001.

NAKANO, Y.; ASADA, K. Hydrogen peroxide is scavenged by ascorbate-specific peroxidase in spinach chloroplasts. Plant Cell Physiology, Kyoto, v. 22, n. 5, p. 867-880, 1981.

SCANDALIOS, J. G. The rise of ROS. Trends Biochemical Science, Cambridge, v. 27, n. 9, p. 483-486, 2002.

VELIKOVA, V.; YORDANOV, I.; EDREVA, A. Oxidative stress and some antioxidant systems in acid rain-treated bean plants. Plant Science, Davis, v. 151, n. 1, p. 59-66, 2000.

VERMA, S.; DUBEY, R. S. Lead toxicity induces lipid peroxidation and alters the activities of antioxidant enzymes in growing rice plants. Plant Science, Davis, v. 164, n. 4, p. 645-655, 2003.

VISSER, E. J. W.; VOESENEK, L. A. C. Acclimation to soil flooding - sensing and signal-tranduction. Plant and Soil, Crawley, v. 254, n. 1, p. 197-214, 2004. 